\title{
Waterborne ammonia and silver catfish, Rhamdia quelen: survival and growth
}

\author{
Sobrevivência e crescimento de jundiá, Rhamdia quelen, exposto à amônia
}

\author{
Denise dos Santos Miron ${ }^{\mathrm{I}}$ Alexssandro Geferson Becker ${ }^{\mathrm{II}, \mathrm{III}}$ Vania Lúcia Loro ${ }^{\mathrm{I}}$ \\ Bernardo Baldisserotto ${ }^{\mathrm{IIIII}}$
}

\begin{abstract}
The aim of the present study was to determine the effects of waterborne un-ionized ammonia $\left(\mathrm{NH}_{3}\right)$ on the survival and growth of silver catfish (Rhamdia quelen). Juveniles were exposed to $0.10,0.22$, and $0.42 \mathrm{mg} \mathrm{L}^{-1} \mathrm{NH}_{3}$ at $\mathrm{pH} 8.2$ for 45 days. After 15 days, a significant mortality rate (33\%) was observed in the fish exposed to $0.42 \mathrm{mg} \mathrm{L}^{-1} \mathrm{NH}_{3}$. After 20 days, $23 \%$ and $43 \%$ mortality (both significant) was observed in fish exposed to 0.22 and $0.42 \mathrm{mg} \mathrm{L}^{-1} \mathrm{NH}_{3}$, respectively. A significant negative relationship between survival, length, daily weight gain, standard growth rate, and biomass of juveniles of silver catfish per tank with waterborne $\mathrm{NH}_{3}$ levels was found at the end of the experiment. The resulting survival and waterborne $\mathrm{NH}_{3}$ relationship indicated that, to avoid any mortality of silver catfish, the maximum level of chronic $\mathrm{NH}_{3}$ exposure at $\mathrm{pH} 8.2$ would be $0.01 \mathrm{mg} \mathrm{L}^{-1}$.
\end{abstract}

Key words: fish culture, nitrogenous compounds, weight gain.

\section{RESUMO}

O objetivo do presente estudo foi determinar o efeito da amônia não ionizada $\left(\mathrm{NH}_{3}\right)$ da água na sobrevivência e no crescimento de jundiá, Rhamdia quelen. Os juvenis foram expostos a 0,10; 0,22 e 0,42mg $L^{-1} \mathrm{NH}_{3}$ em $\mathrm{pH} 8,2$ durante 45 dias. Após 15 dias, uma mortalidade significativa (33\%) foi observada nos exemplares expostos a $0,42 \mathrm{mg} \mathrm{L}^{-1} \mathrm{NH}$. Depois de 20 dias, $23 \%$ e $43 \%$ de mortalidade (ambas significativas) foram registradas nos jundiás mantidos em 0,22 e $0,42 \mathrm{mg} \mathrm{L}^{-1}$ $\mathrm{NH}_{3}$, respectivamente. Uma relação negativa significativa entre sobrevivência, comprimento, ganho de peso diário, taxa de crescimento padrão e biomassa por tanque de juvenis de jundiá, com níveis de $\mathrm{NH}_{3}$ da água, foi encontrada ao final do experimento. A relação entre a sobrevivência e a amônia da água indicou que o nível máximo de $\mathrm{NH}_{3}$ em pH 8,2 para evitar qualquer mortalidade de jundiás em uma exposição crônica deve ser $0,01 \mathrm{mg}^{-1}$.

Palavras-chave: piscicultura, compostos nitrogenados, ganho de peso.

\section{INTRODUCTION}

Ammonia is the main end product from nitrogen metabolism in most teleosts (ISMIÑO-ORBE et al., 2003). This substance is toxic at low concentrations, especially in the $\mathrm{NH}_{3}$ (unionized ammonia) form (FELIPO \& BUTTERWORTH, 2002; MIRON et al., 2008). Reduced growth rates due to $\mathrm{NH}_{3}$ exposure have been reported in several studies involving freshwater fish, but safe levels vary for different species (THURSTON et al., 1981, 1986; ATWOOD et al., 2000; TOMASSO, 1994; EL-SHAFAI et al., 2004; FRANCES et al., 2000).

The culture of silver catfish (Rhamdia quelen) (Quoy \& Gaimard, 1824, Heptapteridae, Siluriformes) occurs mainly in Brazil, and this species was the most commonly raised native species in Rio Grande do Sul state (RS; southern Brazil) in 2001-2005 (BALDISSEROTTO, 2009). Due to its importance for Brazilian fish culture, several studies were performed to determine the best water conditions for improving

IDepartamento de Química, Universidade Federal de Santa Maria (UFSM), Santa Maria, RS, Brasil.

IIDepartamento de Fisiologia e Farmacologia, UFSM, 97105-900, Santa Maria, RS, Brasil. E-mail: bbaldisserotto@ hotmail.com. *Autor para correspondência.

IIIPrograma de Pós-graduação em Zootecnia, UFSM, Santa Maria, RS, Brasil. 
the growth of juveniles of this species (COPATTI et al., 2005; BRAUN et al., 2006; ANDRADE et al., 2007). Biochemical and morphological changes due to shortterm exposure of silver catfish to waterborne $\mathrm{NH}_{3}$ were demonstrated (MIRON et al., 2008; BECKER et al., 2009; CARNEIRO et al., 2009), but no studies assessing chronic exposure have been performed. Thus, the aim of the present study was to determine the effects of waterborne ammonia on survival and growth of this species.

\section{MATERIAL AND METHODS}

Silver catfish juveniles $(11.04 \pm 0.18 \mathrm{~g}$, $11.07 \pm 0.07 \mathrm{~cm}$ ) were obtained from a commercial fish culture near Santa Maria, RS, Brazil. The juveniles were placed in continuously aerated $250-\mathrm{L}$ tanks at a stocking density of 100 juveniles tank $\mathrm{k}^{-1}$. Temperature was maintained at $23-25^{\circ} \mathrm{C}, \mathrm{pH}$ at 7.4 , dissolved oxygen at $7.2 \mathrm{mg} \mathrm{L}^{-1}$, water hardness at $20 \mathrm{mg} \mathrm{CaCO}_{3} \mathrm{~L}^{-1}$, maximum unionized ammonia level at $0.007 \mathrm{mg} \mathrm{L}^{-1}$, and maximum nitrite level at $0.04 \mathrm{mg} \mathrm{L}^{-1}$. The photoperiod was $12 \mathrm{~h}$ light- $12 \mathrm{~h}$ dark. Fish were fed $(5 \%$ total biomass) with commercial food (Purina: $45 \%$ crude protein) twice a day (8:30 a.m. and 5:30 p.m.) during the acclimation period (seven days).

The $\mathrm{NH}_{3}$ levels were $0.10 \pm 0.02 \mathrm{mg} \mathrm{L}^{-1}$, $0.22 \pm 0.02 \mathrm{mg} \mathrm{L}^{-1}$, and $0.42 \pm 0.02 \mathrm{mg} \mathrm{L}^{-1}$, (i.e., 5,10 , and $20 \%$ of the $\mathrm{NH}_{3}$ lethal concentration for $96 \mathrm{~h}$ at $\mathrm{pH} 8.2$, according to MIRON et al., 2008) and $0.005 \pm 0.002 \mathrm{mg} \mathrm{L}^{-1}$ $\mathrm{NH}_{3}$ for the control group. The ammonia levels were reached by adding concentrated $\mathrm{NH}_{4} \mathrm{Cl}$ (ammonium chloride) solution according to BOYD \& TUCKER (1992). Juveniles were placed in continuously aerated 40-L freshwater polyethylene boxes with a stocking density of 10 juveniles box ${ }^{-1}$ (three replicates per treatment) and exposed for 45 days to these different ammonia concentrations.

Temperature $\left(25.0 \pm 0.6^{\circ} \mathrm{C}\right)$ and dissolved oxygen levels $\left(7.3 \pm 0.1 \mathrm{mg} \mathrm{L}^{-1}\right)$ were measured with an oxygen meter (Y5512, YSI Inc., Yellow Springs, USA), and $\mathrm{pH}$ was measured with a DMPH-2 $\mathrm{pH}$ meter (Digimed, São Paulo, Brazil). Nitrite (maximum level was $\left.0.3 \pm 0.1 \mathrm{mg} \mathrm{L}^{-1}\right)$, alkalinity $\left(87.0 \pm 0.1 \mathrm{mg} \mathrm{CaCO}_{3} \mathrm{~L}^{-1}\right)$ and total ammonia $\left(\mathrm{NH}_{3}+\mathrm{NH}_{4}^{+}\right)$levels were determined according to BOYD \& TUCKER (1992) and $\mathrm{NH}_{3}$ levels were calculated as described by PIPER et al. (1982). Water hardness $\left(22.0 \pm 0.1 \mathrm{mg} \mathrm{CaCO}_{3} \mathrm{~L}^{-1}\right)$ was analyzed by the EDTA titrimetric method. All feces and residues were removed daily by suction. Consequently, approximately $20 \%$ of the water in the boxes was replaced by water with previously adjusted $\mathrm{pH}$ and ammonia concentrations.
Forty-five days after the beginning of the experiment, all juveniles were collected for length and weight measurement. The methodology of this experiment was approved by the Ethical and Animal Welfare Committee of the Universidade Federal de Santa Maria. Standard growth rates (SGR) were calculated according to JØRGENSEN \& JOBLING (1993) and total biomass was calculated as mean weight $\mathrm{x}$ number of surviving juveniles. The coefficients of length and weight variation were calculated by the following equation: $\mathrm{CV}=(\mathrm{SD} / \mathrm{M}) \times 100$, where $\mathrm{SD}$ is the standard deviation and $\mathrm{M}$ is the length or weight mean.

The parameters of the different groups were compared by two-way analysis of variance and the Tukey test, with the aid of software Statistica (1997 version). The relationships between the parameters and waterborne $\mathrm{NH}_{3}$ levels were made with the software Sigma Plot 11.0. The minimum significance level was set at $\mathrm{P}<0.05$ and all data are expressed as mean \pm SEM.

\section{RESULTS AND DISCUSSION}

No mortality was observed up to the $15^{\text {th }}$ day. After 15 days, a significant mortality rate (33\%) was observed in the fish exposed to $0.42 \mathrm{mg} \mathrm{L}^{-1} \mathrm{NH}_{3}$. After 20 days, $23 \%$ and $43 \%$ mortality (both significantly different from control) was observed in fish exposed to 0.22 and $0.42 \mathrm{mg} \mathrm{L}^{-1} \mathrm{NH}_{3}$, respectively. Survival and growth parameters of silver catfish decreased with the increase of waterborne $\mathrm{NH}_{3}$. A significant positive relationship between waterborne $\mathrm{NH}_{3}$ levels and silver catfish mortality was observed at the end of 45 days (Figure 1). The relationship between mortality and waterborne $\mathrm{NH}_{3}$ indicates that the maximum levels to avoid any mortality of silver catfish chronically exposed to $\mathrm{NH}_{3}$ at $\mathrm{pH} 8.2$ would be $0.01 \mathrm{mg} \mathrm{L}^{-1}$. This value is close to the safe $\mathrm{NH}_{3}$ level proposed $\left(0.02 \mathrm{mg} \mathrm{L}^{-1}\right)$ by the European Inland Fisheries Advisory Commission (EIFAC, 1973) and the United States Environmental Protection Agency (U.S. EPA, 1977) for freshwater fishes.

Moreover, significant negative relationships between length, daily weight gain, standard growth rate, and biomass of silver catfish juveniles per tank with waterborne $\mathrm{NH}_{3}$ levels were found at the end of the experiment (Figures 1 and 2). The coefficients of variation of length and weight did not present any significant differences between treatments (mean range 3.50-6.15 and 9.81-13.69, respectively). The same negative relationship between waterborne $\mathrm{NH}_{3}$ and weight and length gain after 63 days (pH 7.6-7.8) was found in channel catfish (Ictalurus punctatus) and this 


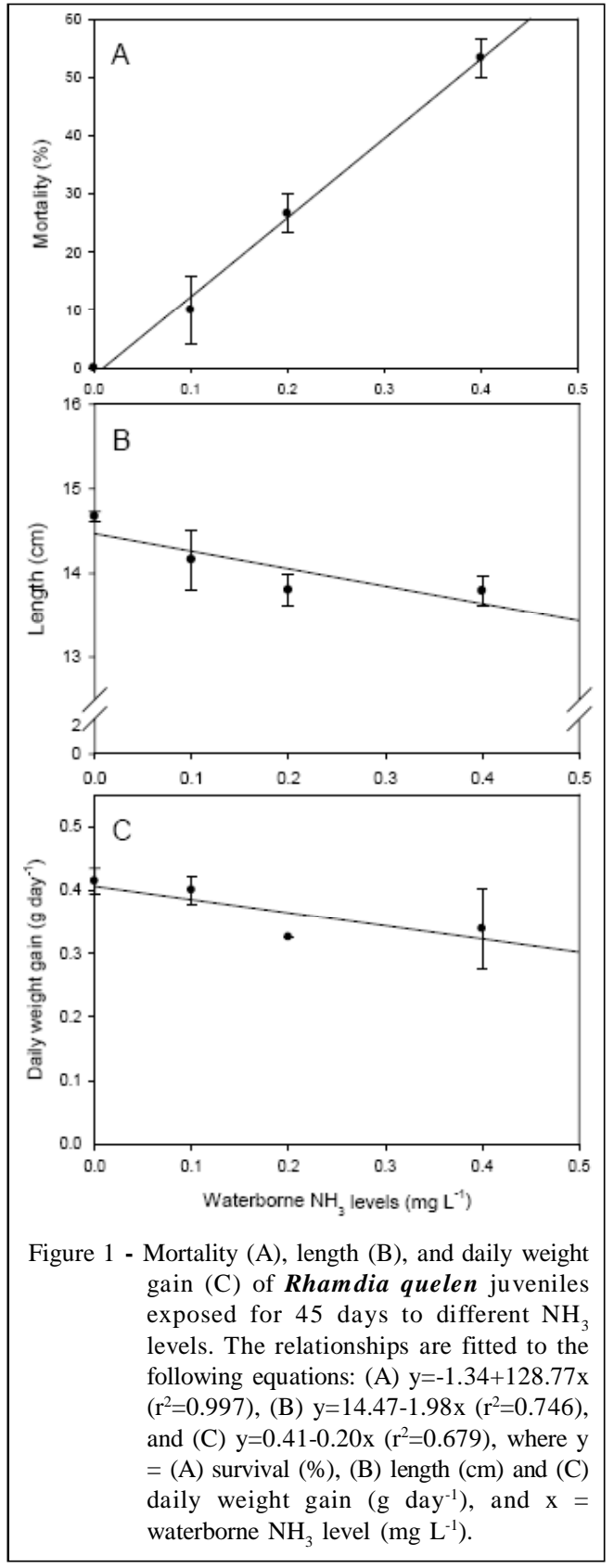

study did not present any safe level for this species (ATWOOD et al., 2000). The safe level for growth of Nile tilapia (Oreochromis niloticus) and silver perch (Bidyanus bidyanus) is $0.060-0.068 \mathrm{mg} \mathrm{L}^{-1} \mathrm{NH}_{3}, \mathrm{pH} 7.3$ 8.1 (FRANCES et al., 2000; EL-SHAFFAI et al., 2004). Fathead minnows (Pimephales promelas) can be raised in up to $0.44 \mathrm{mg} \mathrm{L}^{-1} \mathrm{NH}_{3}(\mathrm{pH}$ around 8.0 ) without significant mortality and growth reduction (THURSTON et al., 1986). Likely, the differences in the values of these $\mathrm{NH}_{3}$ safe levels are related to the protective effect of higher water hardness levels against

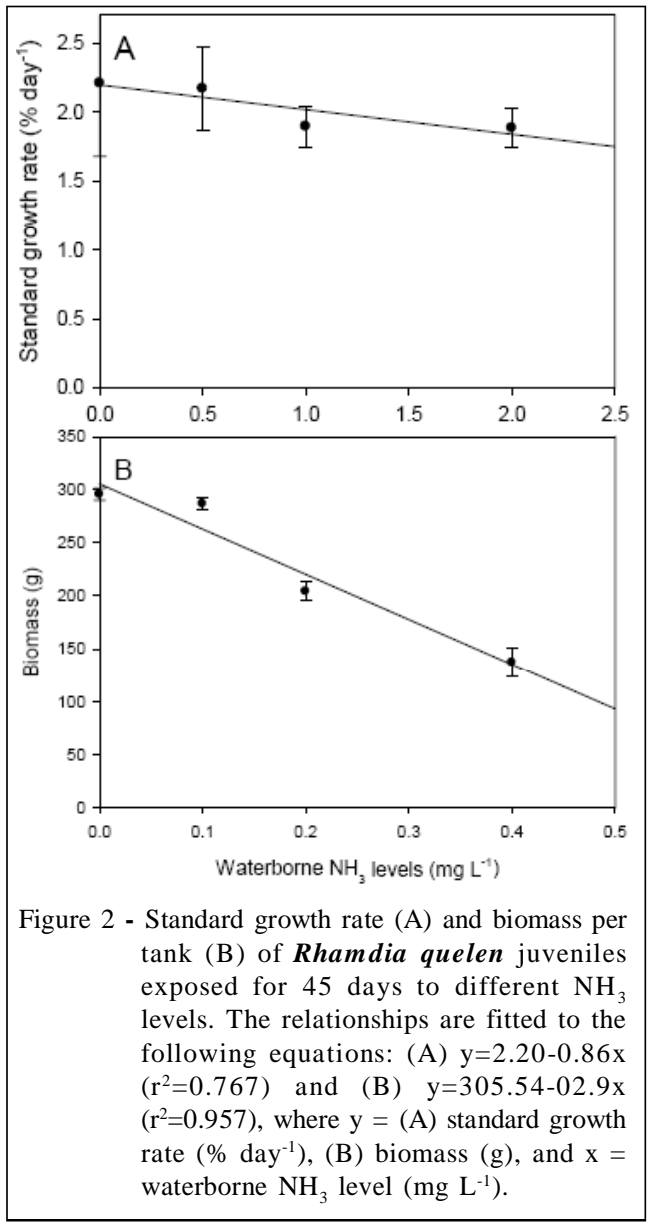

$\mathrm{NH}_{3}$ toxicity (TOMASSO, 1994). In the experiments with Nile tilapia and silver perch, water hardness was 75$120 \mathrm{mg} \mathrm{CaCO}_{3} \mathrm{~L}^{-1}$ (FRANCES et al., 2000; EL-SHAFFAI et al., 2004) and in the experiment with fathead minnows it was 200mg $\mathrm{CaCO}_{3} \mathrm{~L}^{-1}$ (THURSTON et al., 1986).

Additional experiments exposing silver catfish to the $0.01-0.1 \mathrm{mg} \mathrm{L}^{-1} \mathrm{NH}_{3}$ range would be interesting, as rainbow trout maintained for 70 days at 0.013 , but not at $0.041 \mathrm{mg} \mathrm{L}^{-1} \mathrm{NH}_{3}(\mathrm{pH} 7.6$ ), showed higher weight gain and food conversion rates than those kept in $\mathrm{NH}_{3}$-free water (WOOD, 2004). This effect was not observed in channel catfish exposed to the same waterborne $\mathrm{NH}_{3}$ levels (ATWOOD et al., 2000).

\section{CONCLUSION}

The obtained results indicate that the safe $\mathrm{NH}_{3}$ level for silver catfish growth and survival is around $0.01 \mathrm{mg} \mathrm{L}^{-1} \mathrm{NH}_{3}$. However, growth experiments exposing juveniles of this species to the $0.01-0.1 \mathrm{mg} \mathrm{L}^{-1}$ $\mathrm{NH}_{3}$ range might yield good survival results.

Ciência Rural, v.41, n.2, fev, 2011. 


\section{ACKNOWLEDGEMENTS}

This research was supported by the Conselho Nacional de Desenvolvimento Científico e Tecnológico (CNPq), B. Baldisserotto, V. L. Loro and A. G. Becker received CNPq grants.

\section{REFERENCES}

ANDRADE, L.S. et al. Interaction of water alkalinity and stocking density on survival and growth of silver catfish, Rhamdia quelen, juveniles. Journal of the World Aquaculture Society, v.38, n.3, p.454-458, 2007. Disponível em: <http://www3.interscience.wiley.com/cgi-bin/fulltext/ 118534465/PDFSTART>. Acesso em: 14 jul. 2009. doi:10.1111/j.1749-7345.2007.00118.x.

ATWOOD, H.L. et al. Brain monoamine concentrations as predictors of growth inhibition in channel catfish exposed to ammonia. Journal of Aquatic Animal Health, v.12, p.69-73, 2000. Disponível em: <http:// a fsjournals.org/doi/abs/10.1577/15488667(2000)012\%3C0069:BMCAPO\%3E2.0.CO\%3B2. Acesso em: 14 jul. 2009>. doi:10.1577/15488667(2000)012<0069:BMCAPO >2.0.CO;2.

BALDISSEROTTO, B. Piscicultura continental no Rio Grande do Sul: situação atual, problemas e perspectivas para o futuro. Ciência Rural, v.39, n.1, p.291-299, 2009. Disponível em: <http://www.scielo.br/pdf/cr/v39n1/a46cr443.pdf >. Acesso em: 14 jul. 2009. doi:10.1590/S0103-84782008005000046.

BECKER, A.G. et al. Dissolved oxygen and ammonia levels in water that affect plasma ionic content and gallbladder bile in silver catfish. Ciência Rural, v.39, n.6, p.1768-1773, 2009. Disponível em: <http://www.scielo.br/pdf/cr/v39n6/a260cr1136.pdf>. Acesso em: 7 dez. 2010. doi:10.1590/S0103-84782009005000132.

BOYD, C.E.; TUCKER, C.S. Water quality and pond soil analyses for aquaculture. 1992. 183f. Auburn University, Auburn. Disponível em: <http://books.google.com/ books?hl=ptBR\&lr=\&id=Sz4RYEyH5DsC\&oi=fnd\&pg=PR 11 $\& \mathrm{dq}=\% 22 \mathrm{Boyd} \% 22+\% 22$ Pond + aquaculture + water + quality $+\mathrm{m}$ anagement $\% 22+\&$ ots $=$ n0SdXdDjID \&sig=RwTHgTIRJ6t91_FUA GKmUTOZfpg>. Acesso em: 14 jul. 2009.

BRAUN, N. et al. Survival, growth and biochemical parameters of silver catfish, Rhamdia quelen (Quoy \& Gaimard, 1824), juveniles exposed to different dissolved oxygen levels. Aquaculture Research, v.37, n.15, p.1524-1531, 2006. Disponível em: <http://www3.interscience.wiley.com/cgi-bin/ fulltext/118633499/PDFSTART>. Acesso em: 14 jul. 2009. doi:10.1111/j.1365-2109.2006.01589.x.

CARNEIRO, P.C.F. et al. Ammonia-, sodium chloride-, and calcium sulfate-induced changes in the stress responses of jundiá, Rhamdia quelen, juveniles. Journal of the World Aquaculture Society, v.40, n.6, p.810-817, 2009. Disponível em: <http://onlinelibrary.wiley.com/doi/10.1111/j.17497345.2009.00302.x/pdf $>$. Acesso em: 7 dez. 2010. doi: 10.1111/j.1749-7345.2009.00302.x.

COPATTI, C.E. et al. Effect of dietary calcium on growth and survival of silver catfish fingerlings, Rhamdia quelen (Heptapteridae), exposed to different water $\mathrm{pH}$. Aquaculture
Nutrition, v.11, n.5, p.345-350, 2005. Disponível em: <http:/ /www3.interscience.wiley.com/cgi-bin/fulltext/118710612/ PDFSTART>. Acesso em: 14 jul. 2009. doi:10.1111/j.13652095.2005.00355.x.

EIFAC - European Inland Fisheries Advisory Commission. Water quality criteria for European freshwater fish. Report on ammonia and inland fisheries. Water Research, v.7, p.10111022, 1973. Disponível em: <http://www.sciencedirect.com/ science?_ob=ArticleURL\&_udi=B 6V73-4876HFTV\&_us e r $=687358 \&$ \& cover D a t e $=07 \% 2$ F 31 $\% 2 \mathrm{~F} 1973 \&$ _rdoc $=9 \&$ fmt $=$ high \&_orig $=$ browse $\&$ origin $=$ browse\&_zone $=$ rsitt_list_item\&_srch $=$ docinfo $(\% 23$ toc $\% 235831$ $\% 231973 \% 23999929992 \% 23409139 \% 23 \mathrm{FLP} \% 23$ display\%23 Vol ume)\&_cdi $=5831 \& \_$sort $=\mathrm{d} \& \_$docanchor $=\& \_\mathrm{ct}=16 \& \_\mathrm{acct}=\mathrm{C} 00$ 0037899 \&_version $=1 \&$ \&urlVersion $=0 \&$ \&userid $=687358 \& \mathrm{md}$ $5=7$ ee 2401 aac 407 bcadacc $07 \mathrm{~d} 4841 \mathrm{~d} 5 \mathrm{a} 2 \mathrm{a} \&$ searchtype $=\mathrm{a}>$. Acesso em: 15 dez. 2010. doi:10.1016/0043-1354(73)901838.

EL-SHAFAI, S.A. et al. Chronic ammonia toxicity to duckweedfed tilapia (Oreochromis niloticus). Aquaculture, v.232, n.1-4, p.117-127, 2004. Disponível em: <http://www.sciencedirect.com/ science?_ob=MImg\&_imagekey=B 6T 4D-496FTBF-3B\&_cdi $=4972 \& \_u s e r=687358 \&$ \&orig $=$ browse $\& \_$coverDate $=04 \%$ 2F05\%2F2004\&_sk=997679998\&view=c\&wchp $=$ dGLbVzzzSkWz\&m d5 $=6641 \mathrm{c} 25 \mathrm{c} 8 \mathrm{cb} 5697 \mathrm{~b} 311103 \mathrm{eb} 21687 \mathrm{eb} 6$ \&ie $=$ /sdarticle.pdf $>$. Acesso em: 14 jul. 2009. doi:10.1016/S0044-8486(03)00516-7.

EPA - U.S. Environmental Protection Agency. Quality critery for water. Office of water and hazardous materials. Washington, D.C., 1977. 256p.

FELIPO, V.; BUTTERWORTH, R.F. Neurobiology of ammonia. Progress in Neurobiology, v.67, n.4, p.259279, 2002. Disponível em: <http://www.sciencedirect.com/ science?_ob=MImg\&_imagekey=B 6 T 0R-46MBD 51 $2 S \& \_c d i=4869 \& \_u s e r=687358 \&$ \&orig $=$ browse $\& \_$coverDate $=07 \% 2$ F31\%2F2002\&_sk $=999329995 \&$ view $=c \& w c h p=d G L z V l z z S k$ Wb\&md5 =327068cc6293b98d75a3 2b8420ab386f\&ie $=/$ sdarticle.pdf>. Acesso em: 14 jul. 2009. doi:10.1016/S03010082(02)00019-9.

FRANCES, J. et al. Effects of ammonia on juvenile silver perch (Bidyanus bidyanus). Aquaculture, v.183, n1-2, p.95103, 2000. Disponível em: <http://www.sciencedirect.com/ science?_ob=ArticleURL\&_udi=B6T4D3YJYD0G9\&_user=687358\&_cove rDate $=03 \% 2 \mathrm{~F} 01 \% 2 \mathrm{~F} 2000 \&$ rdoc $=9 \& \_\mathrm{fmt}=\mathrm{high} \& \_$orig=browse \&_sr ch $=$ docinfo $\% 23$ toc $\% 234972 \% 232000 \% 23998169998 \% 23160749 \% 23 \mathrm{~F}$ LA\%23display\%23Volume)\&_cdi $=4972 \& \_s o r t=d \&$ docanchor $=\& \_c$ $\mathrm{t}=16 \&$ \&acct $=\mathrm{C} 000037899$ \&_version $=1 \&$ \&urlVersion $=0 \&$ \&userid $=687358 \& \mathrm{md} 5=3 \mathrm{c} 550607 \mathrm{f} 91 \mathrm{c} 0 \mathrm{a} 5044 \mathrm{fd} 1403 \mathrm{fd} 141608 \mathrm{>}$. Acesso em: 14 jul. 2009. doi:10.1016/S0044-8486(99)00286-0.

ISMIÑO-ORBE, R.A. et al. Ammonia excretion by tambaqui (Colossoma macropomum) related to water temperature and fish mass. Pesquisa Agropecuária Brasileira, v.38, n.10, p.1243-1247, 2003. Disponível em: <http://www.scielo.br/ s cielo.php? script = sci_arttext \& pid=S $0100-$ 204X2003001000015>. Acesso em: 14 jul. 2009. doi:10.1590/ S0100-204X2003001000015.

JÆRGENSEN, E.H.; JOBLING, M. Feeding in darkness eliminates density-dependent growth suppression in Arctic charr. Aquaculture International, v.1, n.1, p.90-93, 1993. Disponível em: <http://www.springerlink.com/content/11745j9271156553/ 
$? \mathrm{p}=46725 \mathrm{e} 4715 \mathrm{da} 4666 \mathrm{bd} 7 \mathrm{e} 152968 \mathrm{f} 52206 \& \mathrm{pi}=6>$. Acesso em: 14 jul. 2009. doi:10.1007/BF00692666.

MIRON, D.S. et al. Ammonia and $\mathrm{pH}$ effects on some metabolic parameters and gill histology of silver catfish, Rhamdia quelen (Heptapteridae). Aquaculture, v.277, n.3-4, p.192-196, 2008. Disponível em: <http://www.sciencedirect.com/ science?_ob=ArticleURL\&_udi=B6T4D4RWH87B1\&_user $=6$ $87358 \&$ \&_coverDate $=06 \% 2$ F03\%2F2008\&_rdoc $=11 \&$ _ $\mathrm{fmt}=$ high\&_orig=browse\&_srch=docinfo $(\% 23$ toc $\% 234972 \% 232008$ $\% 23997229996 \% 23688111 \% 23$ FLA \%23 display\%23Volume)\& cdi $=4972 \&$ \&sort $=$ d\&_docanchor $=\&$ \&ct $=28 \&$ \& acct $=$ C00003789 $9 \&$ \&ersion $=1 \&$ \&urlVersion $=0 \&$ userid $=687358 \& \mathrm{md} 5=976 \mathrm{df} 75 \mathrm{c} 2 \mathrm{~b}$ 0164cbc543808d2510594d. Acesso em: 14 jul. 2009>. doi:10.1016/j.aquaculture.2008.02.023.

PIPER, R.G. et al. Fish hatchery management. Washington: United States Department of the Interior Fish and Wildlife Service, 1982. 517p.

THURSTON, R.V. et al. Increased toxicity of ammonia to rainbow trout, Salmo gairdnieri, resulting from reduced concentrations of dissolved oxygen. Canadian Journal of Fisheries and Aquatic Sciences, v.38, n.8, p.983-988, 1981.
Disponível em: <http://rparticle.webp.cisti.nrc.ca/rparticle/ AbstractTemplateServlet?calyLang=eng\&journal=cjfas\&volume $=38 \&$ year $=1981 \&$ issue $=8 \& \mathrm{msno}=\mathrm{f} 81-133>$. Acesso em: 14 jul. 2009. doi:10.1139/f81-133.

THURSTON, R.V. et al. Chronic toxicity of ammonia to fathead minnows. Transactions of the American Fisheries Society, v.115, n.2, p.196207, 1986. Disponível em: <http://afsjournals.org/doi/abs/10.1577/15488659(1986)115\%3C196\%3ACTOATF\%3E2.0.CO\%3B2>. Acesso em: 14 jul. 2009. doi:10.1577/1548-8659(1986)115<196:CTOATF>2.0.CO;2.

TOMASSO, J.R. Toxicity of nitrogenous wastes to aquaculture animals. Reviews in Fisheries Science, v.2, n.4, p.291314, 1994. Disponível em: <http://www.informaworld.com/ smpp/content $\sim \mathrm{db}=\mathrm{all} \sim$ content $=\mathrm{a} 907197342>$. Acesso em: 14 jul. 2009. doi:10.1080/10641269409388560.

WOOD, C.M. Dogmas and controversies in the handling of nitrogenous wastes: is exogenous ammonia a growth stimulant in fish? Journal of Experimental Biology, v.207, n.12, p.2043-2054, 2004. Disponível em: <http://jeb.biologists.org/ cgi/reprint/207/12/2043>. Acesso em: 14 jul. 2009. doi: $10.1242 /$ jeb.00990. 